\title{
Winter Birds of Norway House
}

by Rev. S. C. Fowke, Norway House, Manitoba*

We moved to Norway House from southern Saskatchewan last July. When the last of our migrating friends left last fall for their usual southern resorts we regarded their departure with only the usual amount of regret that we had always felt even while living further south. We assumed that we would still have many winter resident birds to enliven the ice, rocks, and muskeg. It was cnly after careful observation around the settlement and after a few hikes in the half-frozen muskeg during the early part of the winter that we realized how sparse was the bird population of Norway House in winter.

This winter our field trips into the country surrounding Norway House were made on foot before Christmas because the muskeg was not frozen solid enough to carry the bombardier and then on foot with snowshoes along the many creeks and lakes. Our excursions though often strenuous and unproductive-as far as large bird counts were concerned-were always enjoyable.

The only birds that can be called fairly abundant at Norway House in winter are the Common Raven and the Gray Jay. No matter how cold the day we usually saw at least one raven for our efforts. However, there were some days we saw little more. In fact our "counts" were so meagre for the the Christmas Bird Count that it was not until early January that we hit a "lucky" day and saw more than two or three species. The Gray Jays, although uriwelcome to our summer camp sites, were always a welcome visitor when we sat down for a rest or for a bite of frozen lunch. It always interested us to see how quickly this inquisitive fellow showed up just when we were sure there was not a feather for miles around. Our sightings of Gray Jays varied from nil on the thirty below zero days to a high of 17 one lovely ten above zero day when we had to walk home 15 miles because cif a broken bombardier axle.

We were delighted to find the Sharp-tailed Grouse wintering in the muskeg. We saw "chickens" on quite a few occasions and we will be eagerly investigating their residential status this coming spring. We expected to see more Ruffed Grouse than we did but we saw several during the fall. We were especially delighted to see our first Spruce Grouse out in the muskeg. Another first sighting for us was two Willow Ptarmigans seen on the winter road east of Norway House. Large flocks of ptarmigan were reported northwest of here in February but we never had a chance to see them.

There were only two sightings in the owl family for us this winter. On one trip to Playgreen Lake one Snowy Owl was sighted. On a fish hauling trip a Hawk Owl was seen as it flew away from the trail, dropping in its haste a dead Ruffed Grouse.

We expected to find more of the small seed eaters staying with us this winter. However, we saw Common Redpolls only on several occasions. Chickadees were a little more numerous but were still quite scarce. The Boreal Chickadee outnumbered the Black-capped in our recorded sightings.

We were only able to see several Downy Woodpeckers and one Hairy Woodpecker this winter. But now we are eagerly searching for a woodpecker we believe to be Pileated. It was sighted only once at a distance but the call it gave most resembled that of the pileated on the Peterson recordings. If we could find this fellow it wculd be a most exciting addition to our winter bird list.

With the slightly milder weather of March we have found two new birds to watch. Evening Grosbeaks have been seen on several occasions lately and on March 14 a large flock of from 20-30 Pine Grosbeaks were observad at close range for a considerabie length of time. After a fairly birdless winter this last sighting was a real treat. However because of a frozen tape recorder, we failed to get a recording of their merry little whistle.

There were several interesting absentees from our list of winter birds.

* Norway House is located on the north end of Lake Winnipeg. 
At Norway House we are without the flashing black and white of the Black-billed Magpie so common further south. We had always assumed that House Sparrows were everywhere but find that they are not with us at Norway House. No matter how much of a pest and nuisance these two are, we missed seeing them around this winter. Large flocks of Snow Buittings came through last fall and we assumed they would stay for the winte: but they kept on goingwe guess to delight the greater majority cf bird lovers further south. These last two absentees are interesting because we saw both at The Pas during the Trapper's Festival in late February.

With one exception the birds we have written about were seen away from the settlement of Norway House. That one exception, of course, is the raven which is always around to pick over the garbage. This lack of birds arcund our buildings has made us determined to attract as many birds as possible this spring and summer. To this end the building of bird feeders and bird houses has been the order around our household of late. We are already looking forward to the birds' annual spring return and know that in a few weeks our birdless point on Little Playgreen Lake will be alive with flashing colour and cheerful song.

\section{A SOUTHERLY RECORD OF THE WILLOW PTARMIGAN}

\section{by Robert R. Taylor, Regina}

On February 20, 1964, while driving north on highway No. 6 about seven miles north of Dafoe, I spotted a white grouse-like bird walking on top of a snowdrift at the roadside. I stopped immediately and drove back a short distance to get a better look without disturbing the bird. To my surprise it proved to be a Willow Ptarmigan (Lagopus lagopus), a bird with which I am familiar, having spent a summer in the Northwest Territories where this species is common. Although no binoculars were at hand I watched the ptarmigan for several minutes from about fifty feet away and was able to see that it had fully feathered feet. I also noted that it lacked the black eye-stripe characteristic of the Rock Ptarmigan.

This observation is, I understand, particularly noteworthy as the Willow Ptarmigan is rarely found south of the boreal forest.

Editor's Note: Dafoe is about 90 miles north of Regina and well within the aspen parkland, the nearest boreal forest lying some 60 miles or more to the northeast. $H$. Hedley Mitchell (1924. Birds of Saskatchewan) stated that in some winters ptarmigan had migrated southward into the Upper Transition Zone, i.e., into the parkland, and even "rarely south to the Qu'Appelle Valley." E. Manley Callin has informed us that he has been unable to find a documented record for the Qu'Appelle Valley. At Nipawin, more than 100 miles north of Dafoe, Houston and Street $(1959$. Birds of the Saskatchewan River) report "up to 9 noted during 4 out of 15 Christmas counts", so the species is rare and of irregular occurrence even within the southern edge of the boreal forest.

\section{LATE CHRISTMAS COUNTS}

From Stornoway we have a late report (lette: of February 13) of the Christmas count made December 26, 1963, by Richard and Stanley Zazelenchuk, with the following species listed: Goshawk (1), Sharp-tailed Grouse ( 72 ), Horned Owl (1), Blue Jay (1), Black-billed Magpie (4), Black-capped Chickadee (8), House Sparrow (50), Pine Grosbeak (10), Snow Bunting (6).

Goshawks were also noted this winter at Skull Creek, although the usual Christmas count was not made there, since Steve Mann had just returned from hospital before Christmas. Mr. Mann wrote us (letter of February 10): "I rather felt that I was walking out on one of our pet projects by not compiling a Christmas census, as I had been doing it for so many years, but the only thing that I could have done was travel by car and report birds seen, and that doesn't seem very satisfactory. There have been several Goshawks seen in the neighbourhood this year, the odd Golden Eagle, a Pigeon Hawk, Blue Jay, Canada Jay, large flocks of redpolls, Snow Buntings, and Horned Larks. No one has seen very many grosbeaks, either Pine or Evening. Chickadees are quite numerous up and down the creek. We have had ten or twelve at our feeding trays, near the house, all winter." 